\title{
TINJAUAN YURIDIS TERHADAP WANPRESTASI DALAM HAL HUTANG PIUTANG*
}

\author{
Jon Hendri ${ }^{1}$, Khoiri ${ }^{2}$ \\ Kemaritiman, Politeknik Negeri Bengkalis Jl. Bustanul Abidin-Sebauk ${ }^{1}$ \\ *e-mail: jon@polbeng.ac.id \\ STAIN Bengkalis, Jl. Damon-Bengkalis, ${ }^{2}$ \\ e-mail: rie_khay@yahoo.com
}

\begin{abstract}
Kaselan S.Hut has lent money to Abdul Wahid bin Kosmol with the amount of money of Rp. 162,000,000. But abdul wahid bin kosmol wanprestasi until finally to the court but in the trial, the "majelis hakim" did not consider the willingness shown by abdul Wahid to pay off the debts to kaselan. The problem of the study was how the judges's legal considerations in deciding cases Number 1372 K / PDT / 2008 and how about a way to prove the case Number 1372 K / PDT / 2008. Furthermore, the method of this journal was the type of normative research, the source data obtained from three parts of Primary Legal Material, the decision of the Supreme Court and the "Perdata" case No. $1372 \mathrm{~K} / \mathrm{PDT} / 2008$, secondary law materials from books and "hukum tersier". From the results, its can be explained that the "majelis hakim mahkamah agung" in conducting examination of cases Number 1372 K / PDT / 2008 has been through legal procedures as defined by the law. However, in giving legal consideration in deciding the judgment only based on the validity of the agreement made by both parties, regardless of the "eksepsi" filed by the defendant, because the defendant also has good willingness and proven by the payment of the debt in several times. In reviewing the instruments of evidence the "majelis hakim mahkamah agung" only concerns for the evidence presented by the plaintiff, whereas the witness evidence presented by the defendant is not a part of assessment of the "majelis hakim".
\end{abstract}

Keywords: Judicial Review, Default, Accounts Payable

\begin{abstract}
Abstrak
Kaselan S.Hut telah memberikan pinjaman uang kepada Abdul Wahid bin Kosmol sejumalah Rp. 162.000.000 tetapi abdul wahid bin kosmol wanprestasi hingga pada akhirnya sampai kepersidangan tetapi dalam persidangan hakim sama sekali tidak mempertimbangkan I'tikad baik abdul wahid untuk melunasi hutang-hutang kepada kaselan. Masalah yang diteliti adalah bagaimana pertimbangan hukum majelis hakim dalam memutuskan perkara Nomor 1372 K/ PDT/ 2008 dan bagaimana pembuktian dalam perkara Nomor 1372 K/ PDT/ 2008. Sedangkan metode jurnal ini yaitu, jenis penelitian bersifat normatif, sumber data diperoleh dari tiga bagian yaitu Bahan Hukum Primer putusan Mahakamah Agung perkara perdata Nomor 1372 K/PDT/ 2008, bahan hokum skunder yaitu dari buku dan bahan hokum tersier. Hasil dari penelitian ini adalah Dari hasil penelitian ini bahwa Majelis Hakim Mahkamah Agung dalam melakukan pemeriksaan terhadap perkara Nomor 1372 K/PDT/2008 telah melalui prosedur hukum sebagaimana yang telah ditentukan undang-undang. Namun dalam memberikan pertimbangan hukum dalam menjatuhkan putusan hanya berpedoman kepada sahnya perjanjian yang dibuat oleh kedua belah pihak, tanpa memperhatikan eksepsi yang diajukan oleh tergugat, karena tergugat juga mempunyai iktikad baik yang dibuktikan dari adanya pembayaran hutang tersebut dalam beberapa kali angsuran. Dalam mengkaji alat-alat bukti Majelis Hakim Mahkamah Agung juga hanya memperhatikan bukti-bukti yang diajukan oleh penggugat, sedangkan bukti saksi yang diajukan oleh tergugat tidak menjadi penilaian dari majelis hakim.
\end{abstract}

Keyword : Tinjauan yuridis, Wanprestasi, Hutang Piutang

\footnotetext{
* Naskah diterima: 14 Februari 2018, direvisi: 22 Februari 2018, disetujui untuk terbit: 3 Maret 2018
} 
Jon Hendri dan Khoiri: Tinjauan Yuridis terhadap Wanprestasi dalam hal Hutang Piutang

\section{PENDAHULUAN}

Di dalam berkehidupan bermasyarakat, tiap-tiap individu atau orang mempunyai kepentingan yang tidak sama Antara pihak satu dengan pihak lainnya. Terkadang kepentingan mereka ada yang berbenturan dan saling bertentangan, yang mana hal tersebut dapat menimbulkan suatu sengketa masing-masing pihak. Untuk menghindari hal tersebut perlu kiranya suatu aturan yang mengatur aturan tersebut di dalam bermasyarakat agar terciptanya tata tertib agar anggota masyarakat, bisa mematuhi aturan tersebut dan apabila ketentuan tersebut dilanggar akan menimbulkan sanksi bagi si pelanggar. ${ }^{1}$

Di dalam Undang-undang dasar $1945^{2}$ juga mengatur sebagaimana termaktub di dalam pasal 27 ayat 1 Undang-undang dasar republic Indonesia tahun 1945 di dalam ketentuan tersebut berbunyi pada intinya bahwa setiap warga Negara yang ada di Republik Indonesia wajib menjunjung hukum dan pemerintahan tanpa kecuali agar terciptanya sebuah keadilan di dalam kehidupan bermasyarakat, Dalam mencapai kebutuhan hidupnya manusia memerlukan kerja sama dan mereka harus saling mengikatkan diri untuk memenuhi suatu prestasi sehingga timbullah hukum perikatan. Pihak yang harus memenuhi kewajiban sebuah perikatan disebut

1 Ny. Retnowulan Sutantio, Iskandar Oeripkartawinata, 1997, Hukum Acara Perdata dalam Teori dan Praktek, Mandar Maju, Bandung, Hlm. 1

2 Afnil Guza, 2009, UUD 1945 Setelah Amandemen, Asa Mandiri, Jakarta, Hlm. 20 debitur dan pihak yang berhak untuk harus di penuhi pemenuhan dari sebuah perikatan sesuatu perikatan disebut kreditur. Jika tidak dipenuhi atau tidak menepati perikatan disebut cedera janji (wanprestasi). Wanprestasi adalah tidak memenuhi atau lalai melaksanakan kewajiban sebagaimana yang ditentukan dalam perjanjian yang dibuat antara kreditur dengan debitur. ${ }^{3}$ Wanprestasi atau tidak dipenuhinya janji dapat terjadi baik karena disengaja maupun tidak disengaja. ${ }^{4}$ Seorang debitur dikatakan lalai, apabila ia tidak memenuhi kewajibannya atau terlambat memenuhinya tetapi tidak seperti yang telah diperjanjikan. ${ }^{5}$ Mengenai pengertian dari wanprestasi, menurut Ahmadi Miru wanprestasi itu dapat berupa perbuatan:

1. Sama sekali tidak memenuhi prestasi.

2. Prestasi yang dilakukan tidak sempurna.

3. Terlambat memenuhi prestasi.

4. Melakukan apa yang dalam perjanjian dilarang untuk dilakukan. ${ }^{6}$

Apabila seorang dalam keadaankeadaan tertentu beranggapan bahwa perbuatan debiturnya akan merugikan, maka ia dapat minta pembatalan perikatan. Dalam hubungan ini, telah dipersoalkan, apakah perjanjian itu sudah

\footnotetext{
${ }^{3}$ Salim HS, 2008, Pengantar Hukum Perdata Tertulis (BW), Jakarta, Hlm. 180

${ }^{4}$ Ahmadi Miru, 2007, Hukum Kontrak dan Perancangan Kontrak, Rajawali Pers, Jakarta, Hlm. 74

5 Subekti, 2007, Kitab Undang-Undang Hukum Perdata, PT. Arga Printing, Jakarta, Hlm. 146

${ }^{6}$ Ahmadi Miru, 2008, Sakka Pati, Hukum Perikatan, Rajawali Pers, Jakarta, Hlm. 74
} 
batal karena kelalaian pihak debitur ataukah haruslah dibatalkan oleh hakim.

Sehubungan dengan kaus ini yaitu perikatan yang dibuat oleh Kaselan S.Hut dengan Abdul Wahid bin Kosmol bahwa pada bulan Juli 2004 yaitu sekira pukulpukul 19.30 WIB di rumah tergugat Jl. Gatot Subroto Gg. Baru RT. 03 RW. 02 Kel. Kota Bengkalis Kecamatan Bengkalis Kabupaten Bengkalis, Kaselan, S.Hut atas pengakuannya telah menitipkan atau meminjamkan uang untuk sementara kepada Abdul Wahid bin Kosmol uang tunai sebesar Rp. 162.000.000. yang mana pada saat itu dimana bapak Abdul Wahid bin Kosmol membutuhkan uang untuk pembiayaan suatu proyek dan berjanji akan membayarkannya yaitu satu bulan berikutnya sejak tanggal tergugat menerima uang titipan tersebut. Setelah jatuh tempo Kaselan S.Hut akan mengambil uang yang dititipkan kepada tergugat, akan tetapi tergugat tidak bisa mengembalikan uang yang dipinjamnya. ${ }^{7}$

Oleh karena penggugat mengalami kesulitan keuangan dan membuatnya terpaksa meminjam lagi ke seseorang dengan cara menjaminkan tanahnya dan juga bangunan rumah dan segala turunannya yang terdapat di atas tanah tersebut, yang hingga sekarang jaminan/anggunan tersebut telah beralih kepada orang lain, sehingga membuat penggugat menjadi kerepotan dan mengalami kesusahan, namun tergugat tetap tidak juga mau membayarkan

7 Lihat Putusan Nomor: 1372 K/Pdt/2008, Hlm. 1-2. hutangnya tersebut melainkan hanya memberikan janji-janji belaka yang sengaja mengulur-ulur waktu.

Sehubungan dengan tidak adanya kepastian dan hanya janji-janji saja yang didapatkan penggugat dari tergugat maka penggugat melaporkan masalah ini ke yang berwenang sesuai dengan bukti Laporan Polisi No. Pol: LP/11/K/I/2006/SPK/ tanggal 21 Januari 2006. Kemudian pihak tergugat dan penggugat mengadakan suatu musyawarah mufakat untuk mencari suatu penyelesaian yang terbaik dan diadakan di Kantor Kepolisian Bengkalis yang disaksikan oleh beberapa orang saksi. ${ }^{8}$

Pelaksanaan tersebut dilaksanakan pada tanggal 5/3/2005 maka di sepakatilah suatu kata mufakat antara Penggugat dengan Tergugat dengan mengikatkan diri dari masing-masing pihak yaitu melalui suatu perikatan yang intinya bahwa tergugat menyanggupi untuk mengembalikan uang yang dititipkan oleh Penggugat kepada Tergugat dengan cara dua kali angsuran yaitu angsuran pertama adalah $\mathrm{Rp}$. 40.000.000.- akan diserahkan kepada Penggugat pada hari Jumat Tanggal 8 Maret 2005, dan angsuran kedua sebesar Rp. 122.000.000, akan diserahkan kepada penggugat pada hari Jumat Tanggal 8 April 2005, sekaligus sebagai pelunasan sisa hutang Tergugat. Pada tanggal 10 Maret 2005 tergugat telah membayar angsuran pertamanya yaitu $\mathrm{Rp}$. 40.000.000.- (empat puluh juta rupiah).

8 Lihat Laporan Polisi No. Pol: LP/11/K/I/2006/SPK/ tanggal 21 Januari 2006 
Akan tetapi pelunasan angsuran kedua yaitu sebesar Rp.122.000.000 sampai saat ini juga belum direalisasikan. Berdasarkan hal tersebut diatas abdul wahid bin komsol selaku penggugat dalam gugatannya memohon kepada ketua pengadilan bengkalis supaya memberikan putusan sebagai berikut:

1. Agar seluruh gugatannya itu diterima pihak pengadilan serta dan meminta agar sita jaminan dinyatakan sah atas aset-aset berharga baik benda tetap maupun bergerak milik tergugat dalam kasus ini

2. Agar pihak pengadilan menyatakan bahwa kasus tersebut merupakan suatu kasus wanprestasi

3. Menghukum si tergugat membayar pinjaman uang penggugat yang telah diserahkan kepada tergugat dan dan sudah disetujui untuk dikembalikan sebesar Rp. 122.000.000, sekaligus memberikan denda kepada pihak tergugat karena kelalaiannya membayar hutang, sebesar beban bunga bank yaitu Rp. 341.600.000.-

4. Menghukum tergugat membayar kerugian akibat hilangnya hak kepemilikan penggugat diantaranya adalah tanah, bangunan mili si abdul wahid sebesar Rp. 200.000.000, serta menghukum si tergugat agar bisa membayar uang paksa Rp. 100.000 (seratus ribu rupiah) per-hari atas setiap hari keterlambatan tergugat dalam mengimplementasikan putusan ini.

5. Menghukum si tergugat untuk membayar kerugian moril yang diderita penggugat sebesar Rp. 500.000.000.- (lima ratus juta rupiah).

6. Menyatakan putusan ini bersifat serta merta atau keputusan yang dibuat oleh majelis hakim terlebih dahulu dilaksanakan.

Menimbang dengan gugat tersebut maka tergugat mengajukan eksepsi diantaranya adalah gugatan penggugat error in persona, gugatan Penggugat Kurang Pihak Bahwa dalam gugatan tersebut di Pengadilan Bengkalis telah mengambil putusan, yaitu putusan No. 808/Pdt.G/2006/PN.BKS. tertanggal 22 maret 2007 yang amarnya adalah eksepsi dan menolak eksepsi tergugat untuk sepenuhnya.

Pada tingkat kasasi di Mahkamah Agung, Majelis Hakim Agung memberikan putusan, tidak menerima kasasi dari Pemohon Kasasi Abdul Wahid Bin Kosmol. Di sini terlihat tidak ada pertimbangan hakim terhadap eksepsi yang diajukan oleh tergugat, bahwa dalam gugatan ini seharusnya tidak hanya tergugat yang bertanggungjawab tetapi melibatkan pihak lain turut bertanggungjawab, karena uang yang diterima tergugat tersebut adalah dari Iwan Saputra bukan dari penggugat langsung.

Di samping itu juga tergugat telah menunjukkan itikad baik untuk membayar hutang tersebut dengan cara mengangsur, yakni pada tanggal 10 Maret 2005 sebesar Rp.40.000.000,- (empat puluh juta rupiah). Namun sisanya belum bisa dilaksanakan pembayaran kepada penggugat karena belum mempunyai uang. Alasan mendasar tergugat itu tidak dipertimbangkan oleh hakim dalam 
putusan sebagaimana yang penulis gambarkan diatas.

Dari latar belakang di atas tersebut maka penulis tertarik untuk meneliti lebih lanjut permasalahan tersebut, dengan demikian maka penulis memberi judul penelitian ini dengan judul "Tinjauan Yuridis Terhadap Wanprestasi Dalam Hal Hutang Piutang (Studi Kasus Perkara Nomor 1372/K/PDT/2008 Putusan Mahkamah Agung)".

\section{METODE PENELITIAN}

Penelitian merupakan penelitian hukum normatif, yaitu penelitian terhadap wanprestasi dalam hal utang piutang (Studi Kasus Putusan Mahkamah Agung Perkara Nomor 1372 K/PDT/2008). Sedangkan sifatnya adalah deskriptif, yakni menerangkan dan menggambarkan data yang diperoleh melalui pengkajian kasus Nomor 1372/K/PDT/2008, yang berkenaan dengan pertimbangan dan pembuktian yang diungkapkan dalam persidangan.

Sumber Data Penelitian data skunder, yakni: Bahan Hukum Primer adalah bahan utama yang dijadikan pembahasan dalam penelitian ini yaitu berupa putusan Mahkamah Agung perkara perdata Nomor 1372 K/PDT/ 2008. Bahan Hukum Sekunder Bahan hukum sekunder yaitu berupa buku-buku mengenai teori-teori dan pendapat-pendapat para ahli mengenai wanprestasi. Bahan hukum tersier adalah bahan hokum pelengkap seperti kamus hokum, peraturan perundang-undangan dan internet.

\section{HASIL DAN PEMBAHASAN}

Pertimbangan Hakim Dalam Memutuskan Perkara Nomor 1372 K/Pdt/2008 Sebelum penulis melakukan pembahasan terhadap pertimbangan oleh Mahkamah Agung, maka penulis menelaah dan membahas secara singkat tentang pertimbangan-pertimbangan hakim pada tingkat Pengadilan Negeri dan Pengadilan Tinggi dalam menelaah perkara perdata wanprestasi terhadap perkara hutang piutang antara kaselan dengan abdul wahid bin kosmol.

Pertimbangan anggota majelis hakim pada perkara No: 08/ Pdt .G/ 2006/ PN.BKS Beberapa hal yang penulis paparkan di atas bahwa yang menjadi pokok gugatan adalah abdul wahid bin kosmol telah wanprestasi atau cedera janji atas kesepakatan yang telah dibuat bersama pada tanggal 5/3/2005.

Berdasarkan bukti surat perjanjian 5/3/2005 yang dipermasalahkan terhadap persoalan ini yang berisikan suatu kesepakatan perjanjian antara Pengggugat dan Tergugat yang berbunyi: Tergugat menyanggupi untuk mengembalikan uang yang dititipkan oleh Penggugat kepada Tergugat dengan cara dua kali angsuran yaitu angsuran pertama adalah $\mathrm{Rp}$. 40.000.000.- akan diserahkan kepada Penggugat pada hari Jumat Tanggal 8 Maret 2005, dan angsuran kedua sebesar Rp. 122.000.000.- akan diserahkan kepada Penggugat pada hari Jumat Tanggal 8 April 2005, sekaligus sebagai pelunasan sisa hutang Tergugat. Pada tanggal 10 Maret 2005 Tergugat telah membayar angsuran pertamanya 
Jon Hendri dan Khoiri: Tinjauan Yuridis terhadap Wanprestasi dalam hal Hutang Piutang

sebagaimana termuat dalam kesepakatan tersebut diatas yaitu Rp. 40.000.000.(empat puluh juta rupiah). Bahwa akan tetapi pelunasan angsuran kedua yaitu sebesar Rp. 122.000.000.- namun hingga waktu ini juga belum direalisasikan meskipun Penggugat sudah beberapa kali meminta dan memohon supaya sisa uang tersebut di kembalikan kepada Penggugat, bahkan Tergugat menyangkal/tidak mengakui kesepakatan tersebut pada 5/3/2005 dan menyatakan tidak pernah memiliki hutang kepada Penggugat. Terhadap hal Penggugat mengajukan gugatannya PN Bengkalis secara tertulis.

Hal tersebut ditegaskan dalam pasal 118 ayat 1 (HIR), 141 ayat $1 \mathrm{RBg}$ dinyatakan bahwa "tuntutan-tuntutan perdata yang taraf pertama termasuk dalam kekuasaan Pengadilan Negeri dimajukan dengan surat permohonan, yang ditandatangani oleh Penggugat atau kuasanya, kepada Ketua Pengadilan Negeri dalam daerah hukum tempat tinggalnya si Tergugat atau apabila tempat tinggal si Tergugat dengan sebenarnya berdiam". 9 Akibat adanya suatu perbuatan ingkar janji (wanprestasi) yang dilakukan oleh Tergugat terhadap Penggugat tersebut mengakibatkan Penggugat mengalami kesulitan keuangan dan membuatnya terpaksa meminjam lagi ke seseorang dengan cara menjaminkan sebidang tanah berikut bangunan rumah dan segala turunannya yang terdapat diatas tanah tersebut, yang hingga sekarang jaminan/anggunan tersebut telah $\mathrm{RBg}$ beralih kepada orang lain, sehingga membuat penggugat menjadi kerepotan dan megalami kesusahan.

Berdasarkan alasan-alasan diatas Penggugat memohonkan kepada hakim PN Bengkalis untuk memutuskan abdul wahid bin kosmol telah ingkar janji atas perjanjian yang telah dibuat bersama kaselan. serta menyatakan sah isi dari kesepakatan tanggal 5/3/2005. Untuk menjamin adanya kepastian hukum gugatan penggugat dan agar tidak sia-sia penggugat juga memohonkan hakim PN Bengkalis untuk meletakan sita jaminan terhadap harta-harta milik Tergugat atas hutang piutang tergugat kepada Penggugat.

Berkaitan hal tersebut ada baiknya penulis mengemukakan pendapat Sudikno Mertokusumo yang menyatakan bahwa: "penyitaan merupakan tindakan persiapan untuk menjamin dapat dilaksanakannya putusan perdata, barang-barang yang disita untuk kepentingan kreditur dibekukan ini berarti bahwa barangbarang itu disimpan untuk jaminan dan tidak boleh dialihkan atau dijual (214 RBG)". ${ }^{10}$

Berhubungan dengan permohonan Penggugat yang memintakan hakim agar penggugat dinyatakan ingkar janji atau wanprestasi jika dihubungkan dengan pasal 1239 KUH Perdata yang menyatakan "tiap-tiap perikatan untuk berbuat sesuatu, atau tidak berbuat sesuatu, apabila si berutang tidak

10 Sudikno Mertokusumo, 2006, Hukum Acara Perdata Indonesia, Liberty, Yogyakarta, HIm. 89 
memenuhi kewajibannya, mendapatkan penyelesaiannya dalam kewajiban memberikan penggantian biaya, rugi dan bunga". 11

Apabila diperhatikan perikatan yang disepakati oleh Abdul Wahid Bin Kosmol maka perjanjian yang telah dibuat sudah sesuai syarat sahnya suatu perjanjian sesuai pasal 1320 KUH Perdata menyatakan: Kecakapan untuk membuat suatu perikatan Sepakat mereka yang mengikatkan dirinya Suatu hal tertentu Suatu sebab yang halal. ${ }^{12}$ Menanggapi gugatan Penggugat tersebut maka kuasa hukum tergugat mengajukan bantahannya atas gugatan yang ditujukan kepada Penggugat, dimana karena tidak benar pada bulan juli 2004 telah menitipkan dan meminjamkan uang sementara kepada tergugat sebesar Rp. 162.000.000,(seratus enam yang dipergunakan untuk pembiayaan proyek dan akan dikembalikan sebulan berjalan, hal ini terbukti antara penggugat dengan tergugat saat itu tidak ada membuat surat kesepakatan pinjam meminjam dan atau suatu tanda terima baik dalam bentuk kwitansi maupun surat pernyataan penerimaan uang.

Bahwa berdasarkan pada umumnya pada setiap proses penyerahan uang baik untuk kepentingan pinjam meminjam maupun untuk penitipan yang akan dikembalikan kemudian harus disertai dengan surat kesepakatan hutang piutang diikuti tanda penyerahan dan atau tanda terima uang tersebut. "bantahan pada

\footnotetext{
${ }^{11}$ Lihat Pasal 1239 KUH Perdata

${ }^{12}$ Lihat 1320 KUH Perdata
}

hakikatnya bertujuan agar gugatan Penggugat ditolak.

Sementara itu pada umumnya eksepsi diartikan sebuah perlawanan oleh pihak penggugat atas perkara yang berisi tuntutan batalnya gugatan" Untuk menguatkan dalil-dalilnya Penggugat mengajukan bukti-bukti berupa bukti surat yang telah diberi materai cukup yang terdiri dari: salinan Perjanjian antara Abdul Wahid Bin Kosmol dengan Kaselan S.Hut, tertanggal 5 Maret 2005, selanjutnya diberi tanda P-1; Salinan Surat Laporan Polisi No. Pol. LP/11/K/I/2006/SPK tanggal 21 Januari 2006, selanjutnya diberi tanda P-2. Semua bukti berupa fotocopy tersebut telah dibubuhi materai secukupnya dan telah pula dicocokkannya dengan aslinya dan ternyata sesuai benar dengan aslinya. Maka daripada itu dari dokumen atau bukti-bukti yang diajukan di persidangan dapat ditegaskan bahwa telah terjadi kesepakatan yang dibuat oleh Abdul Wahid bin Kosmol dengan Kaselan pada tanggal 5/32005.

Setelah mencermati surat kesepakatan kesepakatan yang dibuat oleh Abdul Wahid bin Kosmol dengan Kaselan pada tanggal 5 Maret 2005 dan ditandatangani kedua belah pihak di hadapan saksi-saksi dan hal tersebut telah dibenarkan oleh keduanya maupun saksisaksi di persidangan, tergugat tidak membantah tanda tangannya dalam surat perjanjian tersebut dokumen perjanjian tersebut telah memenuhi ketentuan Pasal 1320 dan 1338 KUH Perdata. Sementara hakim PTR menimbang putusan No. 
Jon Hendri dan Khoiri: Tinjauan Yuridis terhadap Wanprestasi dalam hal Hutang Piutang

95/PDT/2007/PTR. ${ }^{13}$ Dari keputusan hakim tingkat pertama yang mana menerima gugatan Kaselan maka tergugat mengajukan banding Pengadilan Tinggi Pekanbaru. Sehubungan dengan hal tersebut maka penulis mengemukakan pendapat S. Marbun yang mengemukakan bahwa: "pihak yang tidak menerima putusan pengadilan, dapat mengajukan permohonan banding, permohonan tersebut dilakukan secara lisan maupun tertulis, seseorang atau kuasa yang mengajukan banding harus terlebih dahulu menandatangani akta banding di kepaniteraan PN TK I mengadili perkara itu". 14 Banding merupakan suatu upaya hukum untuk memohonkan ke pengadilan tinggi agar keputusan PN TK I dibatalkan.

Tujuan Lembaga banding diadakan oleh pembuat Undang-undang, oleh karena dikhawatirkan bahwa hakim adalah manusia biasa yang tak lepas dari kesilapan dalam mengambil keputusan. Maka dari itu di buka kemungkinan bagi para pihak yang merasa kalah dalam perkara bisa ajukan memori banding ke kepengadilan Tinggi. Dalam persoalan ini hakim PTR memberikan pertimbanganpertimbangan sebagai berikut: Hakim PTR berpendapat bahwa alasan dalam memberikan pertimbangan hakim PTN TELAH mengambil putusan telah sesuai dan dapat dipertahankan dan dikuatkan, dimana Penggugat di dalam gugatannya mengatakan bahwa si abdul wahid telah ingkar janji karena kesepakatan tanggal 5/3/2005 mempunyai kekuatan hukum,

\footnotetext{
${ }^{13}$ Lihat putusan No. 95/PDT/2007/PTR

14 S. Marbun, 1992, Hukum Acara Perdata Indonesia, UIR Press, Pekanbaru, Hlm. 152
}

sedangkan tergugat tidak melaksanakan isi dari perjanjian dan mengakibatkan si penggugat rugi.

Untuk membuktikan bahwa surat perjanjian tersebut sesuai dengan aturan bisa dilihat pada pasal 1320 dan pasal 1338 KUH Perdata. Dikarenakan belum adanya persamaan kehendak dan kemauan bersama bersengketa yang membuat perjanjian, dimana di dalam pembuatan surat kesepakatan tanggal 05 Maret 2005 belum bisa diterima oleh si terbanding, dikarenakan pembanding belum melaksanakan isi perjanjian tersebut, maka pembanding dinyatakan wanprestasi, dengan hal tersebut penulis mengemukakan pendapat Ahmadi Miru yang menyatakan wanprestasi itu dapat berupa perbuatan: Sama sekali tidak memenuhi prestasi. Prestasi yang dilakukan tidak sempurna. Terlambat memenuhi prestasi. ${ }^{15}$

Melakukan apa yang tidak boleh dalam kesepakatan Maka berdasarkan alasan-alasan tersebut hakim pengadilan tinggi riau dengan putusan No. 95/PDT/2007/PTR yakni menolak banding dari kuasa hukum tergugat/pembanding. Karena tidak dapat membuktikan dalil-dalil gugatanya. Menguatkan putusan pengadilan tingkat pertama No. 08/Pdt.G/2006/PN.BKS. tanggal 12 September 2006. Dalam eksepsi Menolak eksepsi tergugat untuk sepenuhnya.

Dalam Pokok Perkara yaitu: menerima gugatan kaselan sebagian.

15 Ahmadi Miru, Sakka Pati, 2008, Hukum Perikatan, Rajawali Pers, Jakarta, Hlm. 74 
Menyatakan perbuatan abdul wahid bin kosmol perbuatan ingkar janji (wanprestasi). Memberikan sanksi kepada abdul wahid bin kosmol membayar uang penggugat yang telah diserahkan kepada tergugat dan dan sudah disetujui untuk dikembalikan sebesar Rp. 122.000.000.secara cash \& sekaligus. Memberikan sanksi kepada abdul wahid bin kosmol untuk membayar biaya sebesar Rp. 35.9000.- Menolak gugatan kaselan untuk selebihnya. Atas putusan hakim pengadilan tinggi di Pekanbaru tersebut maka pihak abdul wahid bin kosmol atau kuasa hokum yang diberikan tugas untuk mengajukan permohonan Kasasi ke MA.

Pertimbangan Majelis Hakim Mahkamah Agung No: 1372/K/PDT/2008 Permohonan kasasi dalam perkara perdata disampaikan secara prosedur melalui pengadilan negeri Bengkalis yang memutuskan perkara itu, dalam waktu 14 hari setelah keputusan pengadilan tinggi Pekanbaru diberitahukan. Demikian halnya dengan penyelesaian perkara perdata No.1372/K/PDT/2008 pada tingkat kasasi dilakukan sesuai dengan ketentuan hukum yang berlaku di Indonesia, yaitu setiap pihak yang merasa dirugikan dengan putusan pengadilan tingkat pertama berhak mengajukan upaya hukum kasasi baik secara secara tertulis atau lisan melalui pengadilan tingkat pertama yang memutuskan perkara tersebut. ${ }^{16}$

Berdasarkan hal tersebut tergugat/pembanding/pemohon kasasi telah mengajukan permohonan kasasi

\footnotetext{
${ }^{16}$ Lihat putusan perkara No.1372/K/PDT/2008
}

berdasarkan surat kuasa khusus tertanggal 07 Juni 2006 sebagaimana ternyata dalam akta permohonan kasasi No: 08/Pdt.G/2006/PN.BKS yang dibuat oleh panitera pengadilan Negeri Bengkalis. Setelah para pihak menyatakan kasasi dengan menandatangani akta kasasi, maka dalam jangka waktu 14 hari pemohon kasasi harus memberikan memori kasasi.

$\begin{array}{ccc}\text { Dengan } & \text { adanya } & \text { kewajiban } \\ \text { menyampaikan } & \text { memori } & \text { kasasi, dan }\end{array}$ apabila memori kasasi tidak disampaikan maka konsekuensinya tidak bisa diterima. Mahkamah agung memberikan pertimbangan terhadap keberatan pemohon kasasi dalam putusannya No: 1372/K/PDT/2008 pada pokoknya menguatkan keputusan tingakat I dan Pengadilan Tinggi Pekanbaru/Riau memberikan alasan alasan yang disampaikan tidak dapat dibenarkan karena pengadilan tingkat pertama tidak salah dalam menerapkan aturan hukum dan alasan tentang penilaian hasil pembuktian yang bersifat penghargaan tentang sesuatu fakta hal mana tidak dapat dipertimbangkan dalam pemeriksaan tingkat kasasi, karena pemeriksaan pada tingkat kasasi hanya berkenaan dengan adanya kesalahan penerapan hukum, adanya pelanggaran hukum yang berlaku, adanya kelalaian dalam memenuhi syaratsyarat yang diwajibkan oleh peraturan perundang-undangan, yang mengancam kelalaian itu dengan batalnya putusan yang bersangkutan atau apabila Pengadilan tidak berwenang atau melebihi batas wewenangnya, sebagaimana yang dimaksud dalam Pasal 30 Undang-undang 
Jon Hendri dan Khoiri: Tinjauan Yuridis terhadap Wanprestasi dalam hal Hutang Piutang

Tentang Mahkamah Agung (UndangUndang No. 14 Tahun 1985 Jo. Undangundang No. 5 Tahun 2004). Pertimbangan dalam suatu putusan pengadilan merupakan suatu keharusan, hal ini merupakan amanat dari pasal 25 ayat (1) Undang-undang No.4 Tahun 2004 tentang kekuasaan kehakiman yang menyatakan "segala putusan pengadilan selain harus memuat alasan-alasan atau dasar putusan tersebut, memuat pasal-pasal tertentu menjadi dasar untuk mengadili”.

Diharuskan di dalam setiap putusan dari pengadilan memuat alasan-alasan dari putusan baik berdasarkan hukum tertulis maupun hokum yang sifatnya tidak tertulis tetapi hidup dan berkembang di dalam masyarakat juga merupakan asas umum hukum acara perdata, serta pertimbangan, menjadi tanggungjawab hakim terhadap putusannya kepada masyarakat, lembaga pengadilan yang lebih tinggi dan proses hukum yang berlaku.

Oleh karena itu majelis hakim harus senantiasa memperhatikan hal tersebut, sehingga semua pihak dapat menerima dengan puas tanpa cela dan bias, sehingga putusan tersebut mempunyai wibawa. apabila putusan yang dikeluarkan tidak dilengkapi dengan alasan-alasan putusan atau kurang memberikan alasan-alasan dalam keputusan tersebut maka mengakibatkan putusan tersebut batal demi hukum.

Pertimbangan majelis hakim dalam memutuskan perkara perdata No: 1372/K/PDT/2008 yang memutuskan bahwa kesepakatan yang dibuat tertanggal
5/3/2005 adalah sah dan sesuai dengan pasal 1320 KUH Perdata dan Pasal 1338 KUH Perdata No: 1372/K/PDT/2008 berkeyakinan bahwa tergugat telah melakukan perbuatan ingkar janji (wanprestasi) dan surat perjanjian tanggal 5 Maret 2005 adalah sah menurut hukum.

Namun pertimbangan hakim kurang memperhatikan eksepsi dari pihak Tergugat, di sini majelis hakim hanya berpedoman kepada sahnya perjanjian yang dibuat oleh pihak penggugat dan pihak tergugat. Sementara Majelis hakim tidak memperhatikan apa yang sebenarnya terjadi di antara kedua belah pihak sebelum perjanjian itu dilakukan. Mereka sudah ada kata sepakat bahwa penggugat dengan sukarela menitipkan sejumlah uang yang diperkarakan, sehingga menurut penulis hal ini juga harus menjadi pertimbangan dari majelis hakim, tetapi hal ini tidak diperhatikan oleh majelis hakim. Dalam hukum perdata iktikad baik dari seseorang harus menjadi perhatian dari majelis hakim.

Hal ini dapat dilihat bahwa tergugat juga mempunyai keinginan untuk melunasi utangnya kepada penggugat, sebagaimana kesepakatan yang telah disepakati sewaktu berada di kantor polisi. Namun hal ini juga tidak diperhatikan oleh majelis hakim. Dari segi prosedur hukum memang majelis hakim telah melakukan pemeriksaan perkara dengan benar, namun dari segi memperhatikan keterangan masingmasing pihak tidak dilakukan oleh ketua dan anggota majelis hakim, tetapi dari segi proses memang telah sesuai dengan 
hukum, bahwa ketua dan anggota Majelis Hakim pada Mahkamah Agung menolak eksepsi tergugat, dengan alasan sebagai berikut: Tergugat menyatakan bahwa gugatan penggugat Error in Persona.

Pernyataan ini ditolak oleh ketua dan anggota hakim Mahkamah Agung, karena keduanya telah melakukan perjanjian pada tanggal 5/3/2005. Tergugat sebagai pihak yang berhutang disebut sebagai pihak I, dan penggugat adalah sebagai pihak yang meminjamkan uang disebut sebagai pihak II, dan tergugat berjanji menyanggupi pengembalian uang yang dititipkan oleh penggugat kepada tergugat.

Dalam hal ini menurut majelis hakim bahwa penggugat berhak untuk menentukan siap-siapa yang akan digugat, dan seberapa jauh peranan dari pihak yang tidak digugat sehingga terjadinya kasus ini, maka eksepsi tergugat tidak ditemui suatu alasan, maka harus ditolak. Tergugat juga menyatakan bahwa gugatan penggugat kurang pihak, memang yang berhutang kepada penggugat adalah dua orang, namun saudara Iwan Saputra bukan pihak yang menandatangani surat perjanjian, maka eksepsi yang kedua ini menurut majelis hakim juga harus ditolak Kedua hal inilah yang menjadi alasan bagi Majelis Hakim pada Mahkamah Agung menolak eksepsi yang disampaikan oleh tergugat sebagai pihak yang mengajukan kasasi.

\section{SIMPULAN}

Majelis Hakim Mahkamah Agung dalam melakukan pemeriksaan terhadap perkara Nomor 1372 K/PDT/2008 telah melalui prosedur hukum sebagaimana yang telah ditentukan undang-undang. Namun dalam memberikan pertimbangan hukum dalam menjatuhkan keputusan hanya berpedoman kepada sahnya kesepakatan masing-masing pihak, tanpa memperhatikan bantahan yang diajukan oleh tergugat, karena tergugat juga mempunyai iktikad baik yang dibuktikan dari adanya pembayaran hutang tersebut dalam beberapa kali angsuran, tetapi hal ini tidak menjadi penilaian dari majelis hakim, dan majelis hakim lebih memperhatikan alasan-alasan yang diajukan oleh kaselan sebagaimana putusan yang telah dijatuhkan.

Dalam mengkaji alat-alat bukti Majelis Hakim Mahkamah Agung juga hanya memperhatikan alat bukti yang dikemukakan penggugat, sedangkan bukti saksi yang diajukan oleh tergugat tidak menjadi penilaian dari majelis hakim. Dari penjelasan saksi Iwan Saputra dapat dilihat bahwa penyerahan uang titipan tersebut diberikan oleh penggugat kepada saksi Iwan Saputra, dan tidak langsung diterima oleh tergugat, namun dalam pembayaran hutang tersebut tergugat sudah menampakkan iktikad baik tetapi dalam penilaian pembuktian tidak mendapat penilaian dari majelis hakim, dan tetap mengabulkan gugatan penggugat.

Saran Sehubungan dengan uraian dan kesimpulan di atas, penulis memberikan saran sebagai berikut: Kepada majelis hakim di pengadilan, harus dapat memeriksa suatu perkara dengan baik, 
Jon Hendri dan Khoiri: Tinjauan Yuridis terhadap Wanprestasi dalam hal Hutang Piutang

yang memperhatikan semua alat-alat bukti dan dalil-dalil yang dikemukakan oleh masing-masing pihak, baik kaselan sebagai penggugat maupun abdul wahid bin kosmol sebagai tergugat, agar putusan yang diberikan sesuai dengan aturan yang berlaku, dan tidak terkesan berat sebelah dalam memberikan penilaian kepada masing-masing pihak.

Kepada para pihak yang bersengketa, baik kepada kaselan sebagai penggugat maupun abdul wahid bin kosmol sebagai tergugat agar benar-benar jujur dan apa yang terjadi sebenarnya, dalam mengajukan bukti-bukti dan dalil-dalil dalam rangka untuk mengetahui siapa yang sebenarnya yang salah, tanpa membuat rekayasa yang dapat membuat salah satu pihak merasa dirugikan.

\section{UCAPAN TERIMA KASIH}

Alhamdulillah, segala puji hanya milik Allah yang telah melimpahkan rahmat dan karuniaNya kepada Penulis. Akhirnya peneliti berhasil menyelesaikan penelitian ini dengan baik dan tepat pada waktunya, penelitian ini berjudul Tinjauan Yuridis Terhadap Wanprestasi Dalam Hal Hutang Piutang Shalawat dan salam buat teladan umat sepanjang masa, Nabi Muhammad SAW yang telah berjasa besar dengan segenap pengorbanan, beliau berhasil mengantarkan umat manusia kejalan yang diridhoi Allah SWT.

Dalam penulisan penelitian ini penulis telah banyak mendapatkan bantuan dari berbagai pihak, baik secara Moril maupun Materil yang sangat berharga. Oleh karena itu selayaknya penulis mengucapkan terima kasih dan penghargaan yang sebesar-besarnya kepada:

a. Direktur Politeknik Negeri Bengkalis, Ir. Muhammad Milchan, MT, selaku Direktur Politeknik Negeri Bengkalis.

b. Seluruh rekan-rekan Dosen Politeknik Negeri Bengkalis yang tidak dapat penulis sebut satu persatu.

\section{DAFTAR PUSTAKA}

\section{Buku-Buku}

Ahmadi Miru, Hukum Kontrak dan Perancangan Kontrak, Jakarta, Rajawali Pers, 2007

Ahmadi Miru, Sakka Pati, Hukum Perikatan, Jakarta, Rajawali Pers, 2008

Retnowulan Sutantio, Iskandar Oeripkartawinata, Hukum Acara Perdata dalam Teori dan Praktek, Bandung, Mandar Maju, 1997

S. Marbun, Hukum Acara Perdata Indonesia, Pekanbaru, UIR Press, 1992

Salim HS, Pengantar Hukum Perdata Tertulis (BW), Jakarta, 2008

Subekti, Kitab Undang-Undang Hukum Perdata, Jakarta, PT. Arga Printing, 2007

Sudikno Mertokusumo, Hukum Acara Perdata Indonesia, Yogyakarta: Liberty, 2006

Afnil Guza, UUD 1945 Setelah Amandemen, Jakarta, Asa Mandiri, 2009 
Jurnal Cendekia Hukum: Vol. 3, No 2, Maret 2018

\section{Peraturan Perundang-Undangan}

(HIR) RBg

Laporan Polisi No. Pol:

KUH Perdata

LP/11/K/I/2006/SPK/ tanggal 21 Januari 2006

Putusan No. 1372 K/Pdt/2008 PN.BKS

Putusan No. 95/PDT/2007/PTR

Putusan No.1372/K/PDT/2008/MA 